\title{
Reception of Bicultural Identity in Arabic Diaspora Literature: The Works of Elia Abu Madi in Qisshat Al-Adabi Al-Mahjary
}

\author{
Fadlil Munawwar Manshur ${ }^{1}$ \\ ${ }^{1}$ Faculty of Cultural Science, Universitas Gadjah Mada, Yogyakarta, Indonesia \\ Correspondence: Fadlil Munawwar Manshur, Faculty of Cultural Science, Universitas Gadjah Mada, Yogyakarta, \\ Indonesia.
}

Received: January 10, 2020; Accepted: January 26, 2021; Published: February 3, 2021

\begin{abstract}
Literature by the Arab diaspora in the United States has promoted dialectical interpretations of authors' cultural identities, balancing their ancestral cultural identities with those of their new country. In regards to the bicultural identity found in the Arabic-language poetry of Elia Abu Madi, it can be seen that the poet produced several discourses portraying a bicultural reality. The historical essence of Arabic diaspora literature is found not only in its social expressions and representations, but also in the interactions of Arabic and American culture that have produced a bicultural identity. It consists of five key concepts: sign analysis, which functions to reveal the meaning of signs or symbols in the material object; interpreter analysis, which functions to discover the correlations between authors' intents and readers' horizons of expectation; effect analysis, which functions to reveal the influence of literary works on their readers; reference analysis, which functions to reveal authors' repertoires; and context or conditions analysis, which functions to reveal the bicultural identity of authors. This research concludes that, in the author's bicultural identity, the United States is positioned as a prosperous country of dynamic multiculturalism, where people are passionate in their work and art. Meanwhile, Lebanon is positioned as a country where people live mechanically, facing hardship and minimal productivity owing to their lack of security. Conversely, although the United States is prosperous and safe, owing to its orientation towards religious pluralism, its people are more positivistic and material in their lives. They thus tend to ignore spiritual aspects.
\end{abstract}

Keywords: reception, bicultural identity, diaspora Arab poetry, authors, readers, SIERC

\section{Introduction}

The cultures of various societies have diverse levels of development. However, every culture has essential characteristics, which apply universally to all members of that culture - no matter where they are. These essential characteristics are: (i) culture is manifested in and channeled through human behavior, (ii) culture exists before a generation's birth and lives on after that generation's death; though it may change, it will never disappear entirely (Laderman, 2003, p. 203), (iii) culture is practiced by humans and manifested in their behavior, and (iv) culture includes a number of unwritten rules and obligations, behaviors accepted and rejected, and actions recommended and prohibited (Berger, 1964).

Likewise, Arab culture: (i) emerged as a result of Arab behavior, channeled through various cultural works, (ii) was preceded by an existing Arab culture, (iii) is practiced by Arabs in their everyday lives, and (iv) contains specific obligations, recommendations, and prohibitions. In this, Arabic literature functions strategically, helping the Arab people understand how to behave and act in their relations with others and in their own lives. More simply, Arabic is intended to (i) guide interactions between Arab individuals and social groups, (ii) offer a means of channeling their feelings and life experiences, (iii) guide the Arabs in their lives, and (iv) distinguish between humans and animals (Berger, 1964). The core functions of Arab culture is to create meaning, guide the spirit and mind, and expand Arabia from a geographical region into a set of mutually supportive nations.

The Arab people have long been known for being unsatisfied with permanent residence in one place (i.e. one specific country), and are characterized as living highly transient lifestyles. Why have they become such a transient and migratory people, prone to diaspora, moving from place-to-place or even country-to-country? The answer has deep roots in Arab history. Racially, the Arabs are a Caucasian people, part of the Mediterranean group of peoples that trace their roots to the Mediterranean, North Africa, Armenia, Arabia, and Iran. Living in the desert, the Arabs were traditionally a nomadic people, moving from place to place in search of water. Their wanderings followed the sporadic growth of the stepa (grass), which could be found near oases or pools of water formed by rainfall. In 
terms of heritage, the residents of the Arabian Peninsula may be divided into two major groups: the Qahtanites (descendants of Qahthan) and the Adnanites (descendants of Ismail Ibnu Ibrahim as).The Middle East, geographically, includes both Arab and non-Arab countries, such as Turkey, Iran, and Israel. As Turkey practices Turkish culture and Iran practices Persian culture, these countries are not considered Arab. The Arabic culture sphere, rather, consists of parts of the Middle East and North Africa, including Morocco, Algeria, Tunisia and Lybia, which Haikal (1980, p.76) argues experienced no cultural or civilization intersection, except through the acculturation and assimilation of Islam (Bakalla, 1984). Islamic civilization and Arab culture are inseparable, as they have interacted extensively through (for example) culture and language. According to Albert Hourani (2010), "the Arab people are a people with greater awareness of their language than any other people on earth". ArabIslam civilization enjoyed its golden era owing to the contributions of Arab culture and the Arabic language.

Arabic literature, as part of the culture created by the Arabs, has experienced rapid growth over its history, as it has been supported by the Arab literary tradition and love of beautiful language, particularly poetry. This Arab literary tradition became more polished because of its interactions with Islam and its teachings of beauty and goodness. Essentially, the culture and civilization of Islam are derived primarily from Arab culture, including both the modern Arabic literature produced by Arab countries and the literature that has been produced by and developed among the Arab diaspora in non-Arab countries.

Arabic diaspora literature is the literature produced by Arabs who have traveled from their homelands to non-Arab countries. Arabic diaspora literature, known in Arabic as mahjar,is thus Arabic literature produced in non-Arab countries. As a literary entity, Arabic diaspora literature is interesting and important to research as it is produced by authors who live and grow between two cultures. As such, authors of Arabic diaspora literature play two roles simultaneously; they are Arabs who have long lived in their homelands, but also Arabs who have lived and made lives in foreign lands. The bicultural identities of authors of Arabic diaspora literature thus influence their works, be they poems, novels, short stories, dramas, etc. How do authors, as individuals, express their thoughts in these cultures (Lambropoulos, 1987, p.125)? In this case, how did Elia Abu Madi, as a writer, express his thoughts on his native Lebanese culture and on the culture of his new home, the United States?

\section{Method}

The research method used herein relies on the researcher as a reader. In this article, the researcher is positioned within the constellation of readers; the researcher is a reader of the last ranks. A researcher can be categorized as an ideal reader, as manifested through the realized function. Here, objectivity in the scientific method is not the same as in other disciplines. As a reader, the researcher cannot ignore his own subjectivity. In the selection and collection of data for literary research, it is thus important to consider the existence of specific elements. The corpus of literary research is thus partial and open (Chamamah-Soeratno, 2001, p.166). It is a close reading of selected text.

A qualitative research approach is applied in this research. This approach is inspired by the philosophy of rationalism, which promotes the use of a holistic and systemic approach to revealing the meaning hidden behind sensual empiric fact. Epistemologically, research using such a rationalistic approach requires that the research object be included within its context, or at least examined with a specific accentuation or focus without ignoring contextual considerations. Borrowing from Moleong (2002), it may be said that qualitative research departs from a naturalist paradigm, meaning that it assumes that empirical reality occurs within a specific socio-cultural context, the aspects of which are mutually related. As such, every social phenomenon must be discussed in a holistic manner.

In this research, the data collected are the Arabic-language poems collected within Muhammad Abdul Mun'in Khafâjy's anthology Qisshah al-Adabil-Mahjary (1986). Furthermore, secondary data has been collected from written references relevant to the formal object of the researcher. The material object of this research is the Arabiclanguage poetry of Elia Abu Madi collected in Muhammad Abdul Mun'in Khafâjy's anthology Qisshat al-adabi al-mahjary. Its formal object is the bicultural identity presented in Elia Abu Madi's works collected in Muhammad Abdul Mun'in Khafâjy's anthology Qisshat al-adabi al-mahjary.

Based on literary reception theory, which focuses on how readers understand a text, this article holds that it is appropriate to apply the SIERC method proposed by Rien Segers. In this method, SIERC is an initialism, with each letter defined as follows:Smeans signorsymbol, Imeans interpreter, Emeans effect, Rmeans reference, and Cmeans contextor conditions (Segers, 1978, p.15). The reading process involves readers' subjective impressions. However, readers' understandings and perceptions are directed by the textual signs (Jauss, 1983) included in works by literary works by authors. This includes, for example, poems produced and published by the Arab diaspora.

Segers' analytical model, in the context of this research, can be understood as follows. Signs are content, analysis of which (in this case) expresses and reveals the symbols in Elia Abu Madi's poems. Interpreters, meanwhile, 
functions to correlate authors' intentions with readers' horizons of expectation; as such, both authors and readers are interpreters, who explain the potential meaning of a text rather than limit its interpretation to a singular meaning. The entire potential of a text is never realized through reading. As such, it is important to understand specific meanings of the text, as they will recognize the factors that precede the composition of meaning (Jauss, 1983, p.22). Effect, meanwhile, refers to the cultural object being studied by the author. Cultural objects - in this case, literature (poetry) - are products that have certain effects on their consumers (Kristeva, 1979, p.55); effect analysis, thus, seeks to reveal the effect of Arabic diaspora literature (poetry) on readers, broadly defined. Referenceanalysis, meanwhile, serves to reveal authors' repertoires of knowledge and experience-in this article, the repertoires of knowledge and experience of Elia Abu Madi.Context or conditions analysis, meanwhile, functions to identify the bicultural identity of Elia Abu Madi, formed through the intersection of his native culture and the culture of his new country.

This analytical method is operated as follows: (i) the researcher expresses the signs (symbols) contained within Arabic diaspora literature, particularly those used by Elia Abu Madi in his poems to express his bicultural activity, (ii) the researcher reveals the intentions of Elia Abu Madiand his background, as well as the reader-researcher's understanding of the works, (iii) the researcher reveals the effects of Arabic diaspora literature on the development of modern Arabic literature, (iv) the researcher reveals the references, i.e. the repertoires of knowledge and experience, used by Elia Abu Madiin writing his poems, and (v) the researcher reveals the bicultural identity of the community that backgrounded the literary process.

\section{Results and Discussion}

\subsection{The Arabic Diaspora Literature in America}

Arabic diaspora literature developed in non-Arab literature when the Arabs first migrated abroad, primarily in the 19th and 20th centuries. At first, these people migrated from Syria and Lebanon to Canada, the United States, and South America - primarily Brazil, Argentina, Chile, and Venezuela. Through their migration to the West (in the case of Elia Abu Madi, to the United States), Arab writers found new homes and inspirational climates. The earliest years of immigration from Arabia, Lebanon, and Syria to the United States are known as a time of Romanticism, and lasted from 1878 until the late 19th century (Adonis, 2009, p.157).

Through their migration, they influenced Arab culture and the Arabic language through literary works that expressed their feelings, thoughts, traditions, and their longing for their beloved homelands. In these works, authors wrote of the lives they enjoyed in their new countries (Khafâjy, 1986, p.8). Over time, Arabic diaspora literature developed rapidly, not only in terms of works produced but also in terms of content. They wrote of lifestyles, national identities, ideologies, and philosophies, all of which belied their mental turmoil in their new lands.

This rapid growth in Arabic diaspora literature produced a new school of modern Arabic literature, which provided fertile ground for Arabic literary criticism.Known as the Diaspora Literary Community (al-Jamâ'atulAdabiyyahfil-Mahjar), it consisted of several groups. Perhaps most prominent was Ar-Rabithatul-Qalamiyyahyang, established in 1920 by Jubrân, Nu'aymah, Abdul-Masih Haddâd, NadrahHaddâd, Ilyas Athâillah, William Katsiflis, NasîbArîdah, RasyîdAyyûb, Elia Abu Madi, and Wadi' Bahûth (Adonis, 2009:159). Other groups included al'Ushbah al-Andalusiyyah(established in Sao Paulo, Brazil, by Syukrullah al-Jarr), al-Jamâ'atul-Adabiyyah, Jâmi'atul-Qalam, and an-Nawâdy al-Adabiyyahfil-Mahjar(Khafajy, 1986). Of the Arab writers who migrated to the United States, this study focuses on Elia Abu Madi, particularly the poems he wrote while living abroad.

The Arab writers in the United States used the mass media to express their thoughts, establishing their first newspaper Kaukab Amerika in 1892. Seven years later, in 1899, the newspaper Mir'ah al-Arabwas founded to promote Arab nationalism and challenge Turkish power. In 1912, the newspaper as-Sâ ${ }^{i} h$ was founded by AbdulMasîhHaddâd in New York. This newspaper offered space for poets and columnists, be they members of the arRabithatul-Qalamiyyahor not (Adonis, 2009, p.158).

In this situation, several Arab writers gained an international reputation in Arab literature, and they produced numerous critically and popularly acclaimed works. These writers included Jubrân Khalil Jubrân, MichailNu'aymah, and Elia Abu Madi, as well as Muhammad LuthfyJam'ah, Amir Musthafa asy-Syihâby, KhalîlHandawy, Abu Syâdy, Muhammad Mandûr, as-Sahraty, and Khafâjy(Khafajy, 1986, p.12).

Several famed anthologies of Arabic poetry were produced by these authors, including: (i) Dîwânun minasSamâ ỉby Abu Syâdy (New York, 1949), (ii) Dîwânul-Arwâh al-Hâ irah, by NasîbArîdhah, (iii) Dîwânur-rawâfid, by Syukrillah al-Jarr, (iii) Aghâni ad-Darwîsy, by RasyîdAyyûb,and (iv) al-Khamâ ill, by Elia Abu Madi (Khafajy, 1986). 
These writers developed their own unique characteristics, which they exhibited in their works through their stocks of knowledge and experiences, both in their homelands and in their new countries.Writers such as Elia Abu Madi, as part of the Arab diaspora, lived between two cultural situations (Arab and the United States); this makes them interesting for study. As such, this research has taken as its formal object the bicultural identity presented through Arabic diaspora literature, while its material object is the Muhammad Abdul Mun'in Khafâjy's Qisshat al-adabi al-mahjary.

Drawing from this historical background, research on Arabic diaspora literature is important because it presents several problems: (i) how do the symbols in the Arabic diaspora literature produced by Elia Abu Madipresent a bicultural identity? (ii) how did the author function as a translator of his intentions and readers' horizons of expectation? (iii) how do the works of Arabic diaspora literature produced by Elia Abu Madi influence readers?, (iv) how do referential aspects of the poems serve to voice the author's stock of knowledge through literary production?, (v) why is the socio-cultural context important for understanding Elia Abu Madi's bicultural identity?

Works of Arabic diaspora literature produced by Arab authors who had lived in foreign country can be seen as reflecting their thoughts and social experiences in their new lands. In this context, works of Arabic diaspora literature are nothing other than expressions and representations of the Arab diaspora in the United States and South America. To borrow from orthodox Marxist aesthetics, this situation invites a dialectic interpretation of the concept of reflection. The historical essence of a work is rooted not only in its expressive and representative functions, but also in its connections with other works. These connections lead to interactions between works and their readers, as well as coherence with works in their historical environments, which may be seen as reciprocal relationships between production and reception (reading) (Jauss, 1983, pp.11-15).

In this context, the Arab culture of the Arabs in the United States invites dialectic interpretation of authors' reflections and their cultural realities, as well as between their native cultures and the cultures in their new lands. It is important to consider, as "identity is not something that exists; it is not something of universal and essential content; but rather a discursive construct, a product of discourse or directed discussion about the world" (Barker, 2006, p.12).Regarding the bicultural identity expressed in the diaspora poems of Elia Abu Madi, it is apparent that he (the author) produced discourse regarding the intersections between two cultures. Authors of literary works rely on specific ideologies, while literary works depend on the horizons of expectation in their social group (Jauss, 1983, p.26).As such, in writing his poems Elia Abu Madi included a particular ideology, while the text relies on the horizons of expectation of its Arab readers as well as readers from the United States.

Likewise, the historical essence of Arabic diaspora is based not only on its expressive and social representative functions, but also on the interactions between Arab culture - the native culture of the author - and American culture - the new culture that promoted the emergence of a bicultural identity in Elia Abu Madi. How, then, is the reciprocal relationship between Arabic diaspora literature and its reader reception?

The above question has implications for the perspectives of authors living in a global environment, in a new country - in this case, the United States. Authors live in a global context, as cultural globalization has become a reality. Globalization, viewed as a means of increasing human interconnectivity, has influenced various aspects of their everyday lives. Because of globalization, culture has become more complicated and distributed, taking various forms (Held, 2004, p.55).Bicultural identity, in a globalization context, serves as the formal object of this research, which will contribute an understanding of the development of Arabic diaspora literature in the United States.

The theoretical goal of this research is to apply reception theory, which is oriented towards readers, to understand the poems of Elia Abu Madi from a bicultural identity perspective. The practical goal of this research, meanwhile, is to reveal the individual and cultural motivations of Arab authors who migrated to the United States and to explore the bicultural identity present in the poems written by Elia Abu Madiin the United States. This research also seeks to reveal the collective awareness (or, as Roman Jacobson terms it, "collective ideology") underlying this situation. Collective awareness is defined as a system of norms found, in the form of actualized language, within every literary work (Jauss, 1983).In this case, that refers to the collective ideology of the people of Lebanon and the people of the United States, as voiced by Elia Abu Madi through his poetry.

This article offers at least two benefits, specifically a depiction of the individual and cultural motivations of the Arab writers living in the United States, and its revelation of Elia Abu Madi's bicultural identity as revealed in his Arabic diaspora poetry, using him to trace the developmental history of Arabic diaspora literature.Furthermore, these research results also provide a reference for discussion regarding bicultural identity in Arabic diaspora literature, particularly those written by Arab writers in the United States. 
This research is important as little research has examined the concept of Arab writers' bicultural identity within the context of Arabic diaspora literature. To date, research into Arabic diaspora literature (poetry) has focused on the migration of Arab writers from Arabia to non-Arab countries, particularly the United States and South America.

This research into bicultural identity using literary reception theory is hoped to offer a new perspective on the authors of Arabic diaspora literature and their works, both poems and novels. This research takes as its material object the manuscript Qisshat al-adabi al-mahjary, which includes a number of poems written by Elia Abu Madi.

Previous research intoArabic diaspora literature has included, for example, the following. One is an article by Ahmad Atho'illah (2009:219), titled "Sejarah Perkembangan Masyarakat dan Sastra Diaspora Arab-Amerika (Sebuah Tinjauan Sejarah)", included in Adabiyyat(Volume 7, Number 2). It argues that the development of Arabic diaspora literature cannot be separated from the development of the Arab-American community. Arab-Americans, and their literature, have their own unique characteristics. Their lifestyles and literary creativity differ significantly from those of the Arabs in the Middle East.

Syahril, in his article "Adab Mahjar (Sastra Arab Diaspora)", writes that the term diaspora is frequently equated with the Arabic term asy-syatât (الشتات). Etymologically, the word diasporacan be traced to the Greekdia, meaning 'through', and spora, meaning 'spread'. In the Encarta digital dictionary, the word diaspora is defined as the spread or migration of people, languages, and cultures that were once concentrated in a certain place. Initially, the word diaspora referred to the migration of Jews out of Israel. However, since the early 20th century this word has come to refer the general migration of people out of their homelands (Microsoft Encarta Reference Library 2005).

Butler distinguishes between six times of diaspora, namely (i) imprisonment, (ii) exile owing to governmentsponsored eradication, (iii) voluntary or involuntary exodus, (iv) personally initiated emigration, (v) migration, and (vi) imperialism. Edward Said, meanwhile, identifies four types migrants, namely (i) exiles (manfiy), (ii) refugees (lâji '), (iii) expatriates (mughtarib); (iv) emigrants (muhâjir).

My Jelly (2014), in the article "Sastra Diaspora", writes that diaspora literature emerges as a result of a numerous factors, including (i) the migration of Palestinians following the Arab-Israel war of 1948, (ii) the migration of Arabs to Australia, Western Europe, and the United States, and (iii) the rise of limited communities in foreign countries, who established their own media and journalistic organizations-including Ar-Rabithatul-Qalamiyyah, Jami'atul-Adab al-Araby, and Al-Ushbah al-Andalusiyyah - to convey their thoughts.

Furthermore, the characteristics of Arabic diaspora literature cannot be separated from the influences of authors' experiences, be they political, religious, sociological, or psychological. These experienced realities were influenced by the authors' eastern cultures, as well as their traditions, habits, paradigms, and obsessions maintained in their new countries.Authors of Arabic diaspora literature also expressed broad knowledge of classical Arab literature, as well as cultural experiences, longings for their homelands, no matter how politically or socially beleaguered. However, on the other hand, they also had their own understandings of their new countries and languages, and were influenced by the liberty, cultural and social development, and politics found therein.

Here, symbols of bicultural identity refer to the signs of both cultures existing within the poet Elia Abu Madi, namely Arab culture (as the author's native culture) and American culture (as the author's second identity).The following offers the textual data.

\section{Ji`tu la 'alamu min aynawalakinnyataytu \\ Walaqadabshartuamamytharîqanmasyaytu \\ Wasa 'abqasâ 'iran in syi tuhadza am abîtu \\ Kayfaji'tu? Kayfaabshartutharîqy? Lastuadry \\ Innanyji tuwaamdhywaanâ la ‘alamu (Khafajy, 1986:217). \\ I know not whence I came, but I have come \\ Verily before me lay a path, and thus I walked \\ I would walk on, or stop if I so wish \\ How did I come? How did I see the path? I know not \\ Verily my comings and goings, I know not}

The first line, "I know not whence I came, but I have come", indicates that the author (Elia Abu Madi) is telling readers that he has left his homeland (Lebanon) for a new place (country), the United States. However, the poet has seemingly forgotten than he is a Lebanese man who has migrated to the United States. The poet's seeming ignorance of his country of origin indicates that he views his country as being very small, incomparable to the large, progressive, and modern United States. 
The second line, "Verily before me lay a path, and thus I walked",emphasizes to readers that the poet has truly migrated to a new country, the United States, specifically New York City. The author has walked its streets, seen the splendor of its skyscrapers (representative of modern progress), spoken with its heterogeneous and multicultural residents; and observed their disciplined, orderly, and punctual behavior.

The third line, "I would walk on, or stop if I so wish", conveys to readers that the poet perceives the United States as a good country to live, a second home after Lebanon. As such, he will live in his new city, experience happiness and sorrow in New York City.However, he also realizes that he will someday leave the United States if he can no longer endure the longing he feels for his native land. As such, the poet fully recognizes that he will never forget his native land, where he was raised and where he developed as a man of letters.

The fourth line, "How did I come? How did I see the path? I know not", indicates that the poet is not certain of his reasons for migrating from Lebanon to the United States. He does not view his country negatively, let alone allow such perceptions to drive his migration. Indeed, he has no clear reason for migrating to the United States. He is also not sure of what he must do upon arriving in New York City. He can only walk its streets and see its sights.

The fifth line, "Verily my comings and goings, I know not", indicates to readers that the author's arrival in the United States and migration fromLebanon does not guarantee that he will not live in his second country forever. He certainly would always remember his native land, for he remains an Arab, and inherited noble Arab culture and a strong Arab identity.

As such, the poet has begun to sow the seeds of bicultural identity in his speech and in his thoughts. This does not appear to have been deliberate; rather, it is natural for persons who have migrated to another country to find themselves at the intersection of two different cultures.From the above discussion, it appears that the poet has attempted to present Lebanon as a small country and the United States as a big countrythrough his symbols, and to understand these countries through the concept of bicultural identity.

\subsection{Religious Pluralism and Paradox}

Religious pluralism, inthis context, refers to the American people's tendency to respect citizens with diverse religious backgrounds. Meanwhile, paradox refers to statements that appear on the surface to be contradictory or absurd, but are ultimately logical (Abrams, 1981:127).In this context, the culture of the United States is presented as paradoxical or contradictive. For example, a careful study of religious pluralism will enable readers to recognize that religious perspectives are frequently ignored in modern society (Kumar, 2006:10), particularly in the United States, but this religious practice is incongruent with the poet's own understanding. This is evident in the text.

Anâ laghazzun wa dzihaby kamiji iy thalsamu.

Wa alladzy aujada hâdza al-ghazwa laghazzu 'adzamu.

La tujadildzul-hajjy man qâla: lastuadry.

Anâ la unkirusyay an min hayâty al-mâdhiyah.

Ana la 'arifusyay'an 'anhayâty al- 'âtiyah.

Ly dzâtaghayrin 'annylastuadry ma hiyah.

Fa matâta'rifudzâtykinnatundzâty? Lastuadry. (Khafajy, 1986:217).

I come for war, and come like the coming of a tattoo

They started this battle for a greater war

Debate not with the raiders who claim, "truly I do not know"

I will not tell the story of my past

I know not the least of my life to come

I have essence, but I know not what it is

When you know me, is that my essence? I know not.

The first line,"I come for war, and come like the coming of a tattoo", depicts the poet's surprise at seeing the people of New York, plural in color and religion, living in social harmony and cultural dynamicity. The word "war", a cultural context, refers to a society's ethos to promote harmonious and peaceful living, far from conflict and enmity. The word "tattoo", in a cultural context, also refers to physical "power", which references the diligence with which Americans work and create, be it in the field of economics, culture, politics, or even religious pluralism.

Religious pluralism must be defined carefully, as it functions to promote interfaith interactions between the religious groups found in society and in politics. Religion is understood broadly, as covering not only individual faith and charity, but also the social and institutions that bind religious groups. In the United States, pluralism informs the interactions between religious groups in civil society and state institutions. The term religious pluralism indicates a specific social and political phenomenon, but does not imply that the American government is more correct or excellent than the governments of other countries (Banchoff, 2007:16). 
Furthermore, pluralism can rapidly transform into relativism, a view that 'truth' only applies to those who believe it, that what is true for one religious group is not true for another religious group. This can perhaps be understood simplest as meaning that what one group believes to be true is not true for other groups; however, relativism is more than that. At its most basic, it holds that our world is what we think it is (Trigg, 2007:14).As such, for Americans, religious pluralism and relativism simultaneously provide them with intellectual and spiritual energy.

The second line, "They started this battle for a greater war",informs readers that his new life requires hard work and serious dedication. The poet has seen the hustle and bustle of New York City and its diverse population, quite different from the relatively homogenous Arab society of Lebanon, and thus transformed it into an interesting literary object.

The third line, "Debate not with the raiders who claim, 'truly I do not know'", indicates that the poet seeks to avoid debate with people who do not understand the complexity of modern life. In other words, no matter how developed a society, it will still have its shortcomings. Even the United States, considered a developed and industrial nation, there are still criminals who seek the destruction of modern society.

The fourth line,"I will not tell the story of my past",indicatesthat the poet does not want to compare the shortcomings of his native country with the shortcomings of his new country. The poet also seeks to avoid revealing the flaws of American society, as doing so would not be nationalistic. He wants to live peacefully and harmoniously in the United States, without constantly worrying about its flaws.

The fifth line, "I know not the least of my life to come",indicates to readers that the author does not know what will happen to him in his time in the United States, for life in American society is so complex.Rather, the poet seeks to lead his life in the United States with a spirit of optimism, no matter the challenges he faces.

The sixth line, "I have essence, but I know not what it is", illustrates the poet's views of the unique and paradoxical condition of American culture. The word "essence", here, implies a constructive perspective regarding a large country, one referenced by other countries that seek to develop cultures of democracy and egalitarianism. However, this constructive perspective does not guarantee that American culture - representative of Western culture - will always be suited to other countries, such as those in the Middle East.

The seventh line, "When you know me, is that my essence? I know not", emphasizes that, for readers who want to understand the poet's views of the paradoxicality of American culture, he seeks a country that truly cares for humanitarianism, social welfare, peace, and equality for all citizens. However, the poet is also concerned that many people have limited knowledge of American culture.In this, the government of the United States has applied public policy regarding humanitarianism, social welfare, peace, and equality for all citizens, all an implementation of religious pluralism. In a liberal country such as the United States, where religious pluralism is important, the government plays a role - i.e., promoting values — that should be fulfilled by religion (Guinn, 2006:22).

From the above discussion, it can be seen that the poet Elia Abu Madiproduced works that conveyed views of the importance of religious pluralism for Americans, as well as the uniquely paradoxical nature of American culture.

\subsection{Traditional-Mechanic Society versus Organic-Modern Society}

Modern cultural phenomena, in this case the religious pluralism in the United States and multiculturalism embraced therein, are seen as having an influence on authors' paradigms and expressions, as manifested through Arabic diaspora poetry. The following is the textual data.

Nasiyaath-thînusâ' 'atanannahuthînun, haqîrufishâlintayhan wa 'arbadu.

Wa kasa al-khazzu jismahu fa tubahy wa hawa al-malu kaysahu fa tamarradu.

Anta la tashna'u al-harîra alladzy talbasu wa allu 'lu alladzy tataqalladu.

Anta la ta 'kulu an-nidhâra idzâ ji'ta wa la tasyrabu al-jimâna al-midhada.

Anta fi al-burdati al-muwassyâti mitsly fiy kasâliy ar-radîmi tasyqy wa tas'adu.

Laka fiy 'âlami an-nahâari amâny wa ru un wa addzalâmu fauqaka mumtaddu.

Wa liqalby kamâ liqalbika ‘ahlâmu hisânin fa innahu ghayru jalmadin(Khafajy, 1986:238-239).

Clay forgets when it was mud, wet, dirty, and simple

And wealth, from the body dumbfounded, and money its bag,and it fought back

You did not make the silk you wear and did not make the gems you drape on your necks

You are on the most beautiful path, as am I, in the fog hanging over ruins and joys

You do not eat fruit when you hunger, and you do not drink the gems you string

The world of dayis my desire, my dream, and the darkness spread above you

My heart has its dreams, as hearts have dreams, and our hearts are not boulders 
The first line, "Clay forgets when it was mud, wet, dirty, and simple", indicates toreaders that the poet remembers his hometown in Lebanon, an undeveloped yet traditional society. After arriving in New York City, he experienced a stark contrast. The situations in the village and city, in Lebanon and the United States, were very different. In the poet's mind, the situation experienced by the Arab people in his homeland is one of simplicity, traditionalism, and mechanical living. Meanwhile, after living in the United States for several years, he has constructed an understanding of the country as developed and modern, with an organic society.

The second line, "And wealth, from the body dumbfounded, and money its bag, and it fought back,"reflects the socio-economic situation of the American people, who are never left wanting in terms of property, wealth, or title. However, the poet also recognizes that some Americans have protested (fought back) these socio-economic conditions, where the wealthy take pride in their wealth, where the powerful exert their power, and the poor are left wailing in poverty. This is one aspect of American life that indicates paradoxicality. In this, the poet has been influenced by his observations of the United States' modern and often hedonistic society, where worldly and bodily pleasures are sought and success is measured by material achievement.

The third line, "You did not make the silk you wear and did not make the gems you drape on your necks",depicts the situation of the Arabs of Lebanon, who seek equilibriumbetween the worldly or spiritual. As such, the Lebanese Arabs, even when their material needs are fulfilled, do not display their wealth or brag about it to others. In this, the poet is influenced by the paradigm that worldly happiness need not be realized through physical means that are transient and easily broken. The poet recognizes that the American people seem to place great stock in materialism, in physical and material culture, and apply it in their socio-cultural lives.

In the fourth line, "Youdo not eat fruit when you hunger, and you do not drink the gems you string", the poet depicts the socio-economic conditions of the Lebanese Arabs in his homeland, where they cannot eat the foods they desire owing to their economic troubles. They also difficulty attaining prosperity, given the economic conditions of Lebanon.

The fifth line, "You are on the most beautiful path, as am I, in the fog hanging over ruins and joys",depicts the conditions in the poet's new country. He likens life in the United States to a journey that offers him the potential to live a better life, made more democratic owing to the freedoms of expression and opinion guaranteed by law. However, on the other hand, the poet also criticizes his homeland (Lebanon), which he believes does not provide sufficient space for people to express themselves and their opinions.

The sixth line, "The world of dayis my desire, my dream, and the darkness spread above you",depicts the poet's deepest desire to promote prosperity and development among the Lebanese Arabs. Furthermore, the poet also urges the prosperous and wealthy members of Lebanese society to help reduce the sufferings and burdens of their less well-to-do compatriots (my dream, and the darkness spread above you).

The seventh line, "My heart has its dreams, as hearts have dreams, and our hearts are not boulders",again emphasizes that thepoet, as a representative of his people, has a fond desire that the Lebanese Arabs find prosperity and success in all fields and aspects of life. The poet hopes that they will no longer be static, apathetic, stagnant, or lazy in facing the challenges and obstacles in their lives, behavior to which he attributes the failure of previous attempts to lift up the Lebanese Arab people.

From this discussion, it may be concluded that the effects of the socio-economic and cultural situations of Lebanon and United States are among the factors determining the creation of literary works by authors such as Elia Abu Madi. The bicultural identity of Elia Abu Madi is readily apparent in his poetry, an identity created by his living in two different cultures and presented well in his work.

\subsection{National Conflict versus Welfare State}

Here, national conflict versus welfare staterefers to the depiction of Lebanon as being plagued by horizontal conflict and the depiction of the United States as achieving socio-economic prosperity. This is presented in the poetry of Elia Abu Madi, where he compares the conditions in his native land and in his new country. The textual data is presented below.

Inna qashran samaktahu saufa yundika, wa tsauban haktahu saufa yunqidu.

Ji'tu wa al-khubzu wafìrun fiy wathâby wa as-sinâ hauly wa rûhy fiy dhabâbin.

Wa syaribtu al-mâ 'a 'adzban sâ ighan wa ka'any lam adzuq ghayra sarâbin.

Laysa biy da un wa lakinny umru un lastu fiy ardhi wa la bayna shahaby.

Marrati al-ayyamu tatlû ba'dhahum li al-warâ dhahky wa liy wahdy ikti abiy.

Kullamâ istawaladtu nafsy 'amalan maddat ad-dunya lahu kaffu ightishabi.

Aflattu minyy halawâtu ar-ru yâ 'indamâ 'afalat min kaffy syibâby(Khafajy, 1986:247, 255). 
Truly the palace you occupy will crumble, and the clothes you wear will fall

You will hunger, while bread and bounty overflow; a fork beside me, my soul hazy.

I will drink fresh mineral water, as though I have never tasted anything but drink

I am no disease, but I am also a person does not (live) on earth, but also not in the clouds

The days will pass, as some read my laughter behind me, while I truly sorrow

While my soul births dreams, truly the world does violate me

In my mind, joy has vanished, and when it vanished, so ended my youth.

The first line, "Truly the palace you occupy will crumble, and the clothes you wear will fall,"depicts the social reality of the United States, which has attained material prosperity and become a world superpower through its economic and military might. However, according to the poet, the country will one day lose this prosperity if they remain arrogant in dealing with smaller countries with weaker economies. Furthermore, the poet also perceives the American people as frequently showing off their wealth but not being concerned by the suffering of those around them. He argues that such tendencies must be avoided by the people of the United States.

The second line, "You will hunger, while bread and bounty overflow; a fork beside me, my soul hazy,"conveys the poet's criticism of Lebanon, where the poor are unable to eat while the wealthy people around them live lives of plenty. Many wealthy Lebanese have closed their hearts to their fellows and become unwilling to share with their less fortunate fellows.

The third line, "I will drink fresh mineral water, as though I have never tasted anything but the drink, "describes the situation experienced by the author while living in New York, where he drinks mineral water every day, as he did when he was living in his native land. Unlike Americans, he does not consider it necessary to drink alcoholic beverages. However, he occasionally does drink alcohol, attempting to adapt himself to the culture of this modern society.

The fourth line, "I am no disease, but I am also a person does not (live) on earth, but also not in the clouds,"indicates that the poet perceives Americans as being unwilling to accept criticism from anybody or any country; they consider themselves the most correct, given their country's grandeur and prosperity. They feel themselves bored with life on Earth, but they lack the ability to realize life elsewhere.

The fifth line, "The days will pass, as some read my laughter behind me, while I truly sorrow,"indicates the poet's perception of the situation in his native land, which he views as enjoying no respite from conflict between the Lebanese Arabs and the Palestinians fleeing their interminable fighting with Israel. The poet feels upset, as he sees this conflict as disturbing and destabilizing the lives of the Lebanese Arabs. Furthermore, Lebanon has been plagued by conflict with Israel, a Jewish state that accused Lebanon of sheltering Palestinians.Historical records of the conflicts in the Middle East indicates that, after the United States announced its sale of Phantom jets to Israel, Israeli commandos attacked the Beirut Airport in response to Arab guerrillas' destruction of 13 Israeli jets in Athens. This incident brought Lebanon, as well as the rest of Arabia, in direct confrontation with Israel (Lea, 2002:37).Furthermore, between 1975 and 1990 the Lebanese Civil War-fought between Muslims and Christians-led to the deaths of 120,000 people. For years, Lebanon offered a classic example of a fragmented society. During their fifteen-year civil war, the Lebanese killed each other purely for religious reasons, as elsewhere whites and blacks had killed each other and Protestants and Catholics had killed each other (Edwards, 2008:79).

The sixth line, "While my soul births dreams, truly the world does violate me,"presents the poet's horizon of expectation and his desire for his people to emulate the work ethic, discipline, and nationalism of the United States. The poet has observed the progress made by the American people, made possible by theirculturally embedded work ethic, discipline, and sense of pride. As a result, they are expected —or coerced, even — to be correct and orderly in their everyday lives.

The seventh line, "In my mind, joy has vanished, and when it vanished, so ended my youth, "presents the poet's perspective after living in the United States. Lebanese culture has long emphasized values of togetherness and mutual assistance. However, in New York, the poet witnessed a society that promoted individualism, with different members of society existing on their own. Although the American people live in such a manner, they have enjoyed prosperity and an advanced economy. American individualism is characteristic of its pluralism, where individual and collective ideals are valuable means of realizing individual freedoms. According to Habermas' theory of morality, such individualism represents an affirmation of individual autonomy and pluralist values(Brink, 2000:106).

The economic power of the United States is apparent in its millionaires, more than one million in number. Many of them gained their wealth through real estate speculation and the stock markets over the past several decades. 
However, Americans view the world economy as unbalanced, as the wealthy become wealthier and the poor become poorer. Although humanity has made great progress in agriculture, hunger affects more than a billion people worldwide (Sinagatullin, 2003:23).

Based on the above discussion, it may be concluded that the poet has portrayed the socio-economic realities of two countries: Lebanon, a land torn apart by conflict, and the United States, a hegemonic and economic global superpower. From a theoretical perspective, it may be concluded that the referencesof Elia Abu Madi, his repertoire of knowledge and experience, are apparent in his Arabic-language poems.

\subsection{Fatalism versus Positive-Physicalism}

Here,fatalism versus positive-physicalismrefers to the social realities of the Lebanese and of the Americans, as presented by the poet through his diaspora poems. The positivistic paradigm holds that reality is organized by certain universal rules and standards. Truth can be ascertained through probability (Susanto, 2015:595). For Americans, truth is something found in possibility, not in a permanent and final belief. However, for the Lebanese Arabs, truth is something costly, something that cannot easily be "bought". The textual data is presented below.

Ayyuha asy-syâky wa ma bika dầ 'un, kayfa taghdû idza ghadauta 'alilan?

Inna syarra al-jinâti fiy al-ardhi nafsun tatawakkhy qabla ar-rahili.

Wa tarâ asy-syauka fiy al-wurudi, wa ta'my 'an tarâ fauqahâ an-nadâ aklîlâ.

Huwa 'ub un 'alâ al-hayâti tsaqîlun, man yadzunnu al-hayâta 'ib'an tsaqîlan.

Wa alladzy nafsuhu bi ghayri jibâlin, la yarâ fiy al-wujudi syay 'an jamilan.(Khafajy, 1986:258-259).

Oh, you the lamenter, you are no disease; how do you bring the day if your morning is one of illness?

Truly the depravity of the worldly garden is the lust for expectation before realization

You see the thorns on the roses, but are blind to the beads of dew atop them

That is the heavy burden of life, for whosoever believes life to be pointless truly understands not.

And a soul, not high as a mountain, it cannot see the slightest hint of worldly beauty

The first line, "Oh, you the lamenter, you are no disease; how do you bring the day if your morning is one of illness?" conveys an impression that some Lebanese are too quick to complain about the situations they face. These Lebanese people may seem lazy, the poet implies, but this is not their natural state; indeed, the Lebanese people have a good work ethic. However, he warns that this laziness may spread throughout society if the minority inflicts it upon the majority.

The second line, "Truly the depravity of the worldly garden is the lust for expectation before realization, "depicts the condition of the Lebanese elites, who seek power ambitiously and are willing to use any means to realize it. As such, the poet sought to leave his native land because he felt disgusted by the behaviors of its political elites, who seek power while ignoring the suffering of Lebanon's poor and downtrodden.

Meanwhile, the third line, "You see the thorns on the roses, but are blind to the beads of dew atop them,"presents the egotism and individualism exhibited by some Americans in their social lives (You see the thorns), even as they live in a land of wealth and dignity (on the roses). However, these Americans also have their shortcomings, as they fail to consider the guidance offered by religion and are unable to see the spiritual; as a result, they lack balance in their lives, with the worldly being given greater weight than the spiritual and heavenly.

For Americans, 'spirituality' is sometimes difficult to distinguish from religion; simultaneously, it has become increasingly divorced from religious tradition (Sheldrake, 2007:1). As such, Americans have difficulty practicing the teachings of their religions as well as the concepts of spirituality as they understand them. Gunther (in Hicks, 2003:29) views religion as spirituality, and argues that work is a means of conducting spiritual practices. These spiritual practices influence their means of doing business. As such, in the American worldview, the act of attaining worldly prosperity is part of spiritualism, but is not part of religion. In the history of philosophy, meanwhile, the term 'spiritual' has generally not been linked to 'faith', but rather to 'practice' (Cottingham, 2005:17), or more specifically worldly practices intended to attain worldly prosperity.

The fourth line, "That is the heavy burden of life, for whosoever believes life to be pointless truly understands not, "reinforces the previous line, underscoring Americans' tendency to belittle the afterlife. For them, life on Earth is difficult, and thus requires a strong work ethic; how could they imagine life in another realm, a realm in which many no longer believe.

In the United States, there are understandings of the hermeneutics of memory and the hermeneutics of skepticism. The hermeneutics of memory is sympathetic to religion, and as such assumes that human belief is connected to something real and tangible. Their duty is to remember, to manifest 'something' in current times, to convey a message that requires attention. Conversely, the hermeneutics of skepticism rejects the possibility of a sacred or 
religious reality, which it positions instead as an illusion. It holds that it is humanity's intellectual obligation to be skeptical regarding these matters, which it sees as lacking tangible elements for consideration (Phillips, 2003:16).

Americans have embraced such an attitude because the positivistic philosophy that has become deeply rooted in their minds, such that they do not believe in things intangible or invisible. Furthermore, in their everyday lives, Americans tend to embrace a physicalist philosophy in their everyday lives. Although this philosophy may not appear popular, it is nonetheless deeply entrenched in the life philosophies and everyday practices of Americans. Physicalism offers a religious understanding derived from diverse world cultures, positioning the physical world as replete with questions (Mawson, 2005:14). As such, the everyday realities of Americans are essentially questions that require answers.

The socio-ideological condition of the United States cannot be separated from the global situations that have influenced its development. Today, global communities have entered a phase of "personal moating". They are torn apart, wallowing in mud. Their souls and emotions are shorn asunder, and their bodies are weak owing to their burdensome worldly struggles. They seem not to concern themselves with ending their spiritual angst (Briggs, 2006:21), one rooted in their positivism.

The fifth line, "And a soul, not high as a mountain, it cannot see the slightest hint of worldly beauty", provides a detailed characterization of Americans, who consider the afterlife to be unimportant. They allow their souls (spirits) to be empty, even though the afterlife is joyous, exciting, and beautiful. For them, a happy life can only be realized positively, through worldly life. For Americans, happiness, pleasure, and beauty cannot be attained through an uncertain reality (i.e. through the afterlife).

From the above discussion, it is evident that the poet has sought to expose the fatalist social conditions in Lebanon as well as the positivistic and fatalist conditions in the United States. In this condition, it is apparent that the poet has succeeded in writing works of diaspora literature to express his thoughts and bicultural identity.

\section{Conclusion}

In this concluding chapter, several conclusions may be drawn. First, in the author's bicultural identity, Lebanon is understood as too small, particularly in comparison to the United States, a super-modern superpower famed for its progress and its weapons. Second, the United States, as the new country of the author, is viewed as one of religious pluralism and dynamic multiculturalism, passionate in their work and their art; this is seen as having enabled the United States to become a large and prosperous nation. Third, Lebanon is positioned as a traditional country with a people who act mechanically, while the United States is depicted as a modern country with diverse socio-cultural conditions and an organic society.

Fourth, although the United States has become prosperous and a global superpower, this status cannot be maintained forever, as prosperity will fade as American society becomes increasingly arrogant.Fifth, some Lebanese face hardship in life as a result of their lack of security, such that they surrender and accept their situations, despite their productive potential. Meanwhile, Americans feel themselves safe and prosperous, but after embracing religious pluralism they have become more positivistic and material, ignoring the spiritual aspects of life.

\section{References}

Abdel-Meguid, Abdel-Aziz (1994). The Modern Arabic Short Story.Cairo: Al-Ma'rif Press.

Abrams, M. H. (1981). A Glosary of Literary Terms.Fourth Edition. Cornell: Cornell University

Adonis (2009) Arkeologi Sejarah-Pemikiran Arab-Islam.Yogyakarta: LKiS.

Albert, A. Hourani (2010). A History of the Arab Peoples: With a New Afterword. Harvard: Belknap Press of Harvard University Press

Alghaberi, J. A. (2018). The Concept of 'Home'in Palestinian Diaspora Fiction: A Critical Study of Randa Jarrar's Fiction. Langkawi: Journal of the Association for Arabic and English, 4(1), 13-20. https://doi.org/10.31332/lkw.v4i1.765

Atho'illah, A. (2008). Sejarah Perkembangan Masyarakat dan Sastra Diaspora Arab-Amerika (Sebuah Tinjauan Sejarah). Adabiyyât, Vol. 7, No. 2, 2008

Bakalla, M. H. (1984). Arabic Culture through Its Language and Literature. London: Kegan Paul International.

Banchoff, T. (2007). Democracy and the New Religious Pluralism.New York: Oxford University Press. https://doi.org/10.1093/acprof:oso/9780195307221.001.0001

Barker, Chris (2006). Cultural Studies: Theory and Practice. London: Routledge 
Barry, C. B. (2005). Contemporary Paganism: Minority Religions in a Majoritarian America. London: Palgrave Macmillan. https://doi.org/10.1057/9781403973382

Berger, M. (1964). The Arab World Today. New York: Doubleday.

Briggs, M. (2006). Behind The Mask of Religious Traditions. Shippensburg, PA:Destiny Image Publishers.

Brink, Bert Van Den (2000). The Tragedy of Liberalism: An Alternative Defense of Political Tradition. New York: State University of New York Press.

Chamamah-Soeratno, S. (2001). "Penelitian Sastra: Tinjauan Teori dan Metode, Sebuah Pengantar" in Jabrohim (ed.), Metodologi Penelitian Sastra. Yogyakarta: Hanindita Graha Widia and Masyarakat Poetika Indonesia.

Cottingham, J. (2005). The Spiritual Dimension: Religion, Philosophy, and Human Value. Cambridge: Cambridge University Press. https://doi.org/10.1017/CBO9780511614866

Guinn, D. E. (2006). Handbook of Bioethics and Religion.Oxford: Oxford University Press. https://doi.org/10.1093/0195178734.001.0001

Haikal, Muhammad Husain (1980). Sejarah Hidup Muhammad. Jakarta: Pustaka Jaya.

Held, D. (2004). A Globalizing World? Culture, Economics, Politics. New York: Open University. https://doi.org/10.4324/9780203392195

Hicks, D. A. (2003). Religion and the Workplace: Pluralism, Spirituality, Leadership. Cambridge: Cambridge UP. https://doi.org/10.1017/CBO9780511615474

Jauss, H. R. (1983) Toward an Aesthetic of Reception. Minnesota: University of Minnesota.

Khafajy, Muhammad Abdul-Mun'im (1986). Qisshat al-adabi al-mahjary.Beirut: Dârul-Kitâbi al-Lubnâny.

Kristeva, J. (1979). Desire in Language: A Semiotic Approach to Literature and Art. New York: Columbia University Press.

Kumar, P. P. (2006). Religious Pluralism in the Diaspora. Leiden: Koninklijke Brill NV.

Laderman, G., \& Luis, L. (2003). Religion and American Cultures: An Encyclopedia of Traditions, Diversity, and Popular Expressions. California: ABC Clio.

Lambropoulos, V., \& Miller, D. N. (1987). Twentieth-Century Literary Theory.New York: State University of New York.

Lea, D. (2002). A Survey of Arab-Israeli Relations 1947-2001, First Edition. London:Europa Publications Limited. https://doi.org/10.4324/9780203403037

Mawson, T. J. (2005). Belief in God: An Introduction to the Philosophy of Religion.Oxford: Clarendon Press.

Milton-Edwards, B., \& Hinchcliffe, P. (2008). Conflicts in the Middle Eastsince 1945. London: Routledge.

Phillips, D. Z. (2003). Religion and the Hermeneutics of Contemplation.Cambridge: University Press.

Segers, R. T. (1978). The Evalution of Text. Auckland: Peter de Ridder Press, 1978.

Sheldrake, P. (2007). A Brief History of Spirituality. London: Blackwell Publishing.

Sinagatullin, I. M. (2003). Constructing Multicutural Education in a Diverse Society. New York: Lanharn.

Trigg, R. (2007). Religion in Public Life: Must Faith Be Privatized?.Oxford: Oxford University Press.

\section{Copyrights}

Copyright for this article is retained by the author(s), with first publication rights granted to the journal.

This is an open-access article distributed under the terms and conditions of the Creative Commons Attribution license (http://creativecommons.org/licenses/by/4.0/). 